\title{
Perioperative anesthesia in ancient Rome: 27 B.C.-A.D. 476
}

\author{
Valentine Belfiglio* \\ Professor of Government, Texas Woman's University, Texas, USA
}

\begin{abstract}
During the Roman Imperial period countless legionnaires received wounds and injuries requiring surgery. The principles of immediacy and expectancy emphasized that the timing of care after trauma was as important as the quality of care. The use of dissociative (sedation) anesthesia allowed manual and operative procedures for repair of injuries that would have been life threatening without anesthesia. Anesthesia helped to alleviate or minimize the danger of traumatic shock due to an injury or the surgery. This enhanced treatment saved the lives of many Roman soldiers and acted as a force multiplier to give the Romans an advantage in war.
\end{abstract}

\section{Introduction}

The purpose of this article is to better understand the type of anesthesia and techniques employed to prepare patients for invasive surgery in ancient Rome. Roman physicians (Medici) knew that surgery without anesthesia could lead to traumatic shock and even death [1]. Source information is extracted from Greek and Roman writers, Roman artifacts, archaeological discoveries and modern writers. The key concepts to understand are "immediate medical care," "military medicine," "surgery" and "anesthesia." "Immediate medical care" means care rendered soon after a wartime injury by caregivers and clinics or hospitals located near the battlefield [2]. "military medicine" means medical assistance rendered to a wounded soldier with a "primary goal of reducing manpower losses caused by the enemy" [3]. "Surgery" means the use of "operative procedures for repair of injuries" [4]. "Anesthesia" means partial or complete loss of sensation, with or without loss of consciousness due to the administration of an anesthetic agent" [5]. The main assumption of this article is that without excellent medical, including the use of perioperative anesthesia, the Roman army could not have forged an empire. The main point of view is that through successful surgery Roman physicians were able to save many legionnaires and thereby allowed many of them to return to battle after convalescence.

\section{Primary Source Materials}

The most useful ancient writers for this study are Cornelius Celsus (first century A.D.) who dedicated a book to the provinces of surgery and anesthesia, Pedanius Dioscorides (A.D. 40-8) wrote a five volume book that was the precursor to all modern pharmacopeias, Claudius Galenus (129-ca. 200) whose theories dominated Western medical science for well over a millennium, and Flavius Renatus Vegetius ( $4^{\text {th }}$ century A.D.) who discussed sanitation, hygiene and the health of soldiers [6].

\section{Roman Surgery}

The best surgeons (medicus chiurgus) were recruited by the army. Some of these physicians attended medical schools at Alexandria, Egypt or schools located near Athens, Greece. Some secured a residency at a school for gladiators (ludus) in preparation for serving as a surgeon with the Roman legions. Surgery was performed at military hospitals (valetudinarius) located inside a fort (castellum) or camp (castra). The forts and camps varied in size with an average of about five acres per legion, in addition to the fortified ditches, stockades and other defensive devices that surrounded them [7]. Hospitals occupied 6,000 square feet and could accommodate between 250-500 patients.

The valetudinarii of permanent forts were built as firm structures. They were made of brick; concrete, stone, wooden beams and plaster. The roof tiles were made of baked, molded clay and the tiles were fitted together as numerous interlocking pieces, the tiles and were joined together with mortar. Hospitals of less permanent forts or camps were constructed of wood, while those of temporary camps consisted of tents. Permanent hospitals had wards, a surgical suite, corridors, administrative offices dining hall and a drainage system. There were laboratories, kitchens, baths and storage areas [8].

Surgeons had a variety of instruments which allowed them to perform surgery on virtually every part of the body. Examples include: the corvus (surgical knife), cyathiscus (instrument for extracting missiles), volsella (tweezers for removing bone fragments), ferrum candens (cauteries), paxilius (a wedge for treating fractures), trephines for treatment of traumatic brain injury, hooks, bone drills forceps and levers, vaginal and rectal specula, catheters, probes, curettes and several other instruments. All surgical instruments, lint, fibulae, bandages and other surgical materials were boiled in water prior to use for every operation [9]. Hygiene and sanitation were regularly practiced at Roman military hospitals. Rain water was preferred for all medical procedures and preparation of pharmaceutical products. At permanent hospitals an opening in the middle of the roof (compluvium) allowed

${ }^{\star}$ Correspondence to: Valentine Belfiglio, Professor of Government, Texas Woman's University, Texas, USA, Tel: Phone: 940-898-2144; Fax: 940-898-2130; E-mail: vbelfiglio@twu.edu

Key words: Military medicine, Dissociative anesthesia, Surgery, Immediacy, Expectancy

Received: May 18, 2018; Accepted: May 29, 2018; Published: June 01, 2018 
rain to enter and fill collect in a pool (Impluvium). The water was then stored in sealed amphorae. Roman physicians took steps to reduce sepsis by separating sick and wounded soldiers in the hospitals. Every night while others slept, a detachment of soldiers performed hospital police duties (HP). The detail cleaned the entire hospital, especially the surgical suite and used water containing the plant Melissa Officnalis (Lemon Balm) and acetum (vinegar) [10]. Hospital personnel took baths each morning prior to surgery [11].

In an ideal setting four professionals were involved in every surgery. The medicus chirurgus performed the operative procedures for repair of injuries. A chirurgus nutrix (surgical nurse) provided assistance during and after surgery, maintained a clean environment for operations and helped manage the patient after surgery. A medicus ordinarius (medical doctor skilled in in anesthesiology) administered the anesthetic. A miles medicus (hospital orderly) performed ancillary duties not specifically related to the surgical procedure [12].

Under the principles of immediacy and expectancy medici preferred that wounds and injuries be treated on the day they occurred. Capsarii (medical corpsmen) stationed within the legions rendered advanced first aid to wounded legionnaires during battles. They applied pressure to wounds and compressed blood vessels with tourniquets above the wounds of arms and legs. The capsarii applied vinegar to wounds, covered the wounds with a linen bandage and evacuated soldiers by stretchers or ambulances (covered wagons or carts pulled by horses to the valetudinarium [13]. If events did not allow surgery to be performed on the day of injury, the wound could become infected. If this was the case, the surgeon debrided necrotic tissues, cleansed the wound with water then vinegar and could place a drainage tube with the sutured, wound. Honey could be placed over the wound before it was bandaged with linen.

\section{Roman Perioperative Anesthesia}

Some Roman medicii specialized in anesthesiology. Only the healthiest and strongest young men were admitted to the legions. The harsh training and regular fatigue duties kept the legionnaires in outstanding physical condition [14]. Under the modern ASA physical status classification system most military patients would be in ASA 1 (healthy person) if surgery was performed on the day of the injury [15]. However in a mass casualty situation, when triage was employed, many legionnaires could have been classified higher on the scale. Roman anesthetists employed the Dissociative (sedation) (twilight) method of anesthesia. Sedatives were given with strong analgesics and local anesthetics. The patient would experience catalepsy, amnesia and marked analgesia [16]. The analgesic of choice was powdered opium (Papaver somniferum) in a draft of wine [17]. However, opium had to be imported from the East via the Silk Road and might not be available in sufficient quantities during mass casulaties. In that case the anesthetist would administer powdered mandrake (Mandragora officinarium) in a draft of wine [18]. Mandragora officinarium was grown in Italy. The sedative powdered Corn poppy (Papaver rhoeas) was added to the wine [19]. The local anesthetic used in surgery was a mixture of Memphitic stone and henbane seeds (Hyoscyamus niger) ground up and smeared on areas about to undergo surgery [20]. Once the patient was administer these agents and was in a state of twilight sleep the surgeon began to operate. Operations were conducted as quickly as possible.

The anesthetist continually monitored the condition of the patient for signs of hemorrhagic or traumatic shock and other complications. The most outstanding symptoms of shock are marked paleness of the skin and cyanosis. Other symptoms include: sweaty, cool and pale skin, restlessness, anxiety, thirst, confusion, hyperventilation, nausea and vomiting. The anesthetist would ensure that the patient was warm, elevate the feet higher than the level of his heart, loosen clothing wherever it may be binding, calm the patient and turn his head to the side to prevent choking should he vomit [21].

\section{Postoperative Care}

Postoperative care was an important phase of Roman medicine. Hemorrhagic shock and infection were common problems. To restore blood the legionnaire received foods rich in heme iron and non-heme iron. This might include broth made from meat, poultry and seafood. As the soldier's health improved, bits of meat, legumes, leafy greens, and white mushrooms were added to the broth. Then nuts, prunes, olives, mulberries, whole grains, dried thyme were added to the diet [22]. Roman physicians knew nothing about the correlation of heme and non-heme iron's value in treating anemia. They merely knew through trial and error over many generations, which foods best restored a soldier's vigor after loss of blood and recorded their findings. Antiseptics such as vinegar and honey were important in keeping infections under control [23]. Control over inflammation and fever were also important aspects of postoperative care.

The choice herb to control inflammation was turmeric (Curcuma longa). It was given internally and applied externally to wounds [24]. Unfortunately, this plant had to be imported from India or China along the Silk Route. When it was not available Roman physicians used rosemary (Rosmarinus officinalis) grew well in Europe and was used as an anti-inflammatory [25]. Fever was controlled in several ways. Convalescent staff sponged patients with a draught containing a powder made from the bark of a willow tree (Salix) [26]. When the fever was quite high, the head of the patient was kept cool with ice or cold compresses, and his body kept warm with blankets. Constipation or diarrhea could be problems in post-surgery recovery. Tannin containing plants were commonly used for diarrhea. An example is oak bark (Quercus robur) [27]. Of the many herbs used for constipation linseed is often cited ((Linum usitatissimum) [28]. Nausea and vomiting can also complicate a patient's recovery after surgery. Roman physicians used a number of herbs to control these symptoms. An example is ginger (Zingaber officinale) [29]. To control coughs Roman physicians prescribed horehound (Marrubium vulgare) to treat coughs. There were hundreds of other medicines prescribed and administered at Roman military hospitals.

\section{Conclusion}

During the Roman Imperial period countless soldiers received wounds and injuries requiring surgery. The principles of immediacy and expectancy emphasized that the timing of care after trauma was as important as the quality of care. The use of dissociative (sedation) anesthesia allowed manual and operative procedures for repair of injuries that would have been impossible without anesthesia. Anesthesia helped to alleviate or minimize the danger of traumatic shock due to an injury or the surgery. This enhanced treatment saved the lives of many legionnaires and acted as a force multiplier to give the Romans an advantage in war.

\section{References}

1. Thomas CL (1754) Taber's Cyclopedic Medical Dictionary. PA: F.A. Davis, Philadelphia.

2. Kiran Panesar (2013) Advances in Wound Management, U.S. Pharmacist. Phar 6: 13-16. 
3. Richard AG, Karen SM (1992) History of Military Medicine. Greenwood, New York pp. 1: 2.

4. Thomas CL (1869) Taber's Cyclopedic Medical Dictionary.

5. Thomas CL (2001) Taber's Cyclopedic Medical Dictionary.

6. Cornelius Celsus, De Medicina (1961) Cambridge: Harvard University Press; Pedanius Dioscorides, De materia medica (2017) Zurich: Hildesheim; Claudius Galenus, De Methodo Medendi (2011) Cambridge: Harvard University Press; Flavius Renatus Vegetius, De Rei Militaris (1993) Liverpool: Liverpool University Press.

7. Vegetius, De Rei Militaris, 3.8; 1.21-25.

8. Richard AG (2011) The Best Medicine, Military History 28: 36-41.

9. Celsus De Medicina, 7.1-3, 8.125.4; Galen, De Methodo Medendi, 7.6 445K-446K.

10. Michael Heinrich (2012) Melissa Officinalis contains polyphenolics and an essential oil which possess antimicrobial effects. Vinegar contains acetic acid which is an antiseptic. Celsus, De Medicina, 5.2; Fundamentals of Pharmacognosy and Phytotherapy, Churchill Livingstone London pp: 254-255.

11. Celsus, De Medicina, I.III-IV.

12. John Scarborough (1969) Roman Medicine, Ithaca, New York: Cornell University Press pp: 70-75.

13. Richard AG, Karen SM (1992) A History of Military Medicine, London: Greenwood Press 1: 166-167.

14. Flavius Renatus Vegetius, De Rei Militaris (1993) Liverpool: Liverpool University Press 1.6, 8.28.

15. Fitz-Henry J (2011) The ASA classification and peri-operative risk. Ann R Coll Surg Engl 93: 185-187. [Crossref]
16. Clayton (1921) Taber's Cyclopedic Medical Dictionary, 101.

17. Dioscorides. De Medica Materia, 4.64.3. Opium is a powerful analgesic containing morphine, codeine and thebaine.

18. Dioscorides, De Medica Materia, 4.75.3. Mandrake is a less potent analgesic containing scopolamine, hyoscyamine and atropine.

19. Dioscorides, De Medica Materia, 4.63.2. Corn poppy contains rhoeadine, a mild sedative.

20. Dioscorides, De Medica Materia, 4.68.3, 5.140. Henbane contains scopolamine and hyoscyamine. Memphitic stone contains retinasphalt.

21. Galen, De Methodo Medendi, 5.1-15, 305K-383K; Celsus, De Medicina, 7.1-33.

22. Dioscorides, De Medica Materia, 1. 105, 126, 2. 19, 22, 33, 46, 49, 58, 107, 4.169.

23. Vinegar contains acetic acid, which is an antiseptic. Honey has several antibacterial components. These components include: defensin-1, hydrogen peroxide and methylglyoxal. The high sugar content of honey and its low $\mathrm{pH}$ adds to its antibacterial qualities. Dioscorides, De Medica Materia, 2.82.1-2, 5.13.1.

24. Rosemary contains carnosol and carnosic acids which are strong anti-inflammatory agents. Dioscorides, De Medica Materia, 3.75.

25. Willow bark contains salicylic acid, an anti-febrile. Dioscorides, De Medica Materia, 1.104 .

26. Tannins are astringent, polymeric polyphenols and useful in the treatment of diarrhea Dioscorides, De Medica Materia, 1.106.1.

27. Linseed is a bulk-forming laxative with a high percentage of fibre. Dioscorides, De Medica Materia, 2.103.

28. Ginger contains zingiberene and b-bisabolene which are carminatives. Dioscorides, De Medica Materia, 2.160.

Copyright: $(02018$ Belfiglio V. This is an open-access article distributed under the terms of the Creative Commons Attribution License, which permits unrestricted use, distribution, and reproduction in any medium, provided the original author and source are credited. 